\title{
FEEDING HABITS OF CHAOBORIDAE LARVAE IN A TROPICAL BRAZILIAN RESERVOIR
}

\author{
ARCIFA, M. S. \\ Departamento de Biologia, FFCLRP, Universidade de São Paulo, CEP 14040-901, Ribeirão Preto, SP, Brazil \\ Correspondence to: Marlene Sofia Arcifa, Departamento de Biologia, FFCLRP, Universidade de São Paulo, Av, \\ Bandeirantes, 3900, CEP 14040-901, Ribeirão Preto, SP, Brazil, e-mail: marcifa@usp.br \\ Received December 3, 1999 - Accepted January 5, 2000 - Distributed November 30, 2000
}

(With 5 figures)

\begin{abstract}
The diet of the four larval instars of a Chaoboridae species of Lake Monte Alegre, was evaluated through the analysis of the crop content of individuals caught at night in the lake. Peridinium and zooflagellates were the major components of the diet of instars I and II, whereas microcrustaceans, especially the cladoceran Bosmina, were most important for late instars. When the preferential prey decreased, in the course of the year, the diet was more diversified, increasing the ingestion of Peridinium by instars III and IV. There is a relationship between the mouth diameter of the larvae and the maximum width, height, or diameter of the ingested organisms.
\end{abstract}

Key words: Chaoboridae, four instars, diet, zooplankton, omnivory.

\section{RESUMO}

\section{A dieta de larvas de Chaoboridae em um reservatório tropical brasileiro}

A dieta dos quatro estádios larvais de uma espécie de Chaoboridae do Lago Monte Alegre foi avaliada por meio de análise do conteúdo do papo de exemplares coletados no lago, à noite. Peridinium e zooflagelados constituíram os principais itens da dieta dos estádios I e II, enquanto, os microcrustáceos foram mais importantes para os estádios III e IV, principalmente o cladócero Bosmina. Quando da diminuição das presas preferenciais no decorrer do ano, houve maior diversificação da dieta, aumentando o consumo de Peridinium pelos estádios III e IV. Verificou-se que há relação entre o diâmetro da boca das larvas e os valores máximos de largura, altura ou diâmetro dos organismos ingeridos.

Palavras-chave: Chaoboridae, quatro estádios, dieta, zooplâncton, onivoria.

\section{INTRODUCTION}

Chaoboridae larvae are peculiar organisms in the sense that they can be part of the plankton and benthos, depending on the time of the day and the instar. They are considered an important zooplankton predator, being responsible, in some lakes, for the control and sometimes supression of prey populations (Neill, 1981; Elser et al., 1987). But larvae can be also omnivores, consuming algae, mainly phytoflagellates (Elser et al., 1987; Hare \& Carter, 1987; Shei et al., 1988; Moore, 1988; Moore et al., 1994). Actually, due to their motility, these organisms could be sensed as animals by
Chaoboridae larvae. As an omnivore, Chaoborus would lose its status of predator, but the importance of algae in the diet varies from lake to lake.

The long-wise ingestion of rigid prey (Moore \& Gilbert, 1987), makes relatively long but narrow organisms vulnerable. The way prey moves is also important for its capture.

In the tropics, differently from the majority of temperate lakes, reproduction is continuous (McGowan, 1974; Lewis, 1975; Reiss, 1977; Cressa \& Lewis, 1984; Hare \& Carter, 1986; Arcifa, 1997). Consequently, predation pressure would be also continuous throughout the year, varying according to seasonal fluctuations in Chaoboridae 
densities. The migratory behaviour of larvae and prey would minimize predation pressure, in a diel cycle.

In Lake Monte Alegre, higher values of Chaoboridae density occurred in summer (Arcifa et al., 1992; Arcifa \& Meschiatti, 1993). Nocturnal vertical migration is more conspicuous in instars III and IV than in I and II (Arcifa, 1997).

The subject of this paper is the diet evaluation of the four larval instars of a Chaoboridae species of Lake Monte Alegre. The temporal variation of the diet and the relationship between the mouth diameter of the larvae and dimensions of prey were also analysed, as well as the selectivity of cladoceran prey.

\section{STUDY AREA}

Lake Monte Alegre $\left(21^{\circ} 11^{\prime} \mathrm{S}, 47^{\circ} 43^{\prime} \mathrm{W}\right)$ is a small, shallow, eutrophic, and warm discontinuous polymictic reservoir (area $7 \mathrm{ha}, \mathrm{Zmax}=5 \mathrm{~m}, \overline{\mathrm{z}}=$ $2.9 \mathrm{~m}$ ). Located in southeastern Brazil, at an altitude of $500 \mathrm{~m}$, resulted from the damming of Laureano Creek, which belongs to Pardo River basin, in 1942. It may stratify for relatively long periods in the warm season, leading to oxygen depletion at the bottom (Arcifa et al., 1990). As the outlet is superficial and the dam is not manipulated by man, it functions as a small lake, having a retention time of $c a .45$ days. Temperature ranged from 18 to $31^{\circ} \mathrm{C}$, conductivity (at $25^{\circ} \mathrm{C}$ ) from 47 to $96 \mu \mathrm{S} . \mathrm{cm}^{-1}$, pH from 5.5 to 8.0 and supersaturation of dissolved oxygen was common (Arcifa et al., op. cit.). The region is characterized by a tropical climate of transition between warm and sub-warm, with marked dry-cool season (MaySeptember) and wet-warm season (October-April).

\section{MATERIAL AND METHODS}

Larvae for crop evaluation were taken from samples collected in 1985/86, at night, with a 60 $\mu \mathrm{m}$ mesh net, and fixed with $4 \%$ formalin. The reason for using these samples was that concomitant data on prey, algae, and physical and chemical factors were also available (Arcifa et al., 1990, 1992).

The material contained in the crops of larvae I to IV was analysed. Individuals were selected in the samples and put on a slide, where the fixative was replaced by drops of tap water. The head of each individual was then pulled with a needle, resulting in the extraction of part of the gut from the exosqueleton. The gut was then cut just in front of the crop, and its content squeezed with a gentle pressure of the needle. The material in each drop was then analysed with a microscope or stereomicroscope.

A total of 443 individuals with crop contents was analysed: 85 of instar I, 127 of II, 86 of III, and 145 of IV, from samples throughout the year. The diet was evaluated by counting prey and by the mean relative volume occupied by items, considering all the crops of each instar. Whenever possible prey were measured at the microscope, and the mouth diameter of larvae at the stereomicroscope, according to Swift \& Fedorenko (1975).

Chesson's electivity index (1978) was used for calculation of selectivity of cladoceran species by larvae IV.

\section{RESULTS}

\section{Overall composition and temporal variation of the diet}

The total body length of the instars were: I) $1.20 \pm 0.31 \mathrm{~mm}$, II) $2.39 \pm 0.41 \mathrm{~mm}$, III) $3.55 \pm$ $0.15 \mathrm{~mm}$, and IV) $6.14 \pm 0.74 \mathrm{~mm}$.

The overall diet of instar I was basically composed of the dinoflagellate Peridinium (55\%) and zooflagellates $(21 \%)$, rotifers being a minor item (9\%) (Fig. 1). To these items, microcrustaceans and other algae were added to the diet of instar II. The contribution of Peridinium, zooflagellates, and rotifers dropped, increasing that of cladocerans to the diet of instars III and IV $(55 \%$ and $68 \%$, respectively). The contribution of copepod was less than $5 \%$ to the diet of instars III and IV, other algae reaching $8 \%$ in the instar III.

Keratella cochlearis micracantha was the main rotifer prey, $K$. americana, Epiphanes macrourus and Conochilus dossuarius being seldom ingested. Bosmina was clearly the main cladoceran prey, representing $96 \%$ and $82 \%$ of the ingested cladocerans by instars III and IV, respectively. Daphnia gessneri was the second most important cladoceran prey, Moina micrura and Ceriodaphnia cornuta appearing sometimes in the crop contents. Instar II fed on pre-reproductive Bosmina, whereas instars III and IV consumed also ovigerous and non-ovigerous Bosmina. 

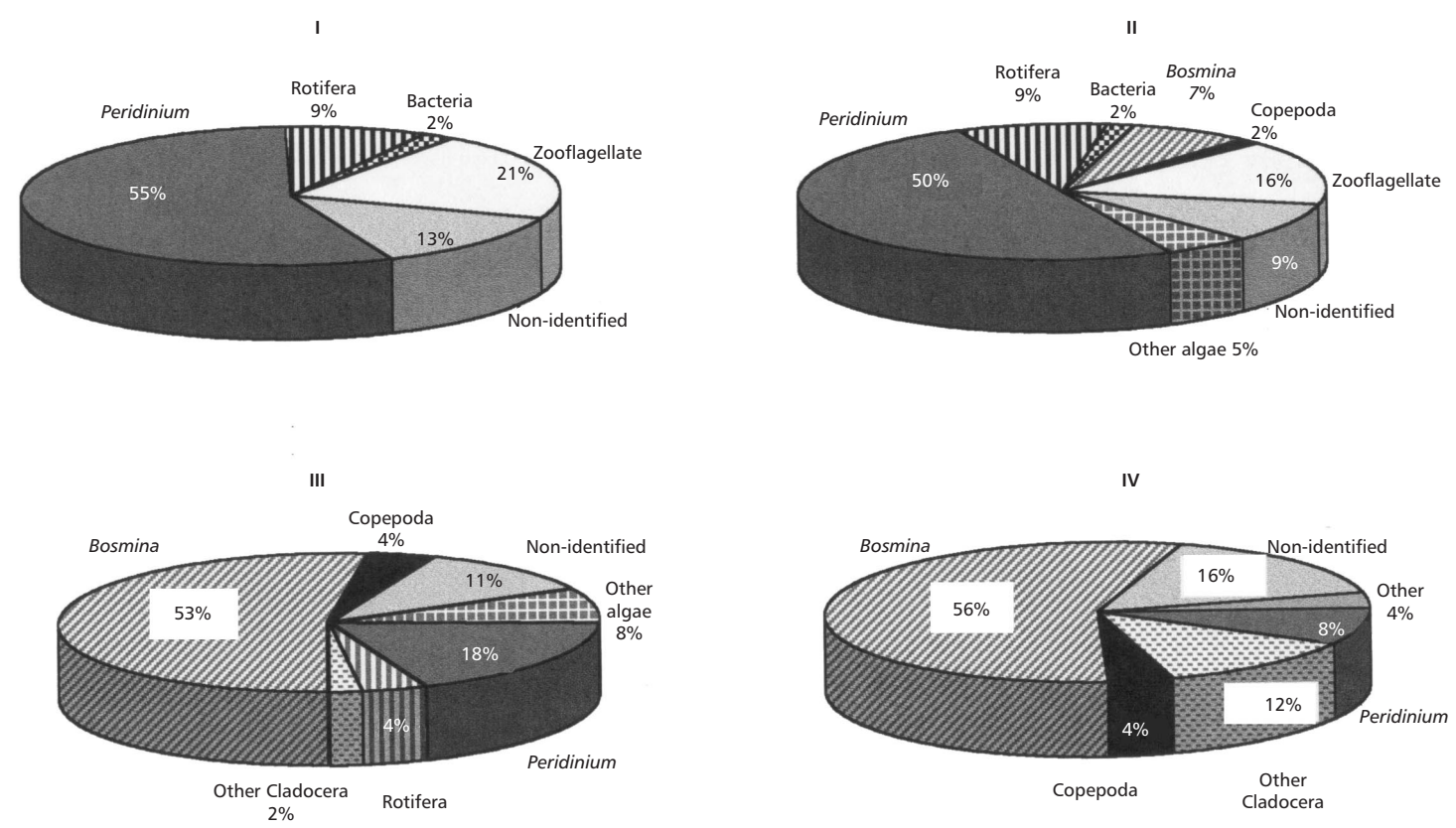

Fig. 1 - Relative proportions of items in the diet of the larvae I to IV.

The maximum prey number in a crop content was seventeen Bosmina found in a larva III, and thirty Peridinium in a larva IV.

The item "non-identified", which was composed by macerated organisms, non-recognizable debris and structures, was important in the diet of all instars. It is possible that soft organisms were part of this item. "Other algae" included Aulacoseira, Arthrodesmus, Microcystis, Phacus and diatoms.

Temporal variation in the proportion of ingested items occurred during the year (Fig. 2). Higher diversification of items and an increase of nonpreferential prey contribution occurred whenever the availability of the preferential ones decreased. In April-May, the virtual absence of Peridinium in the lake (Fig. 3) caused an increase in rotifers and non-identified items in the diet of instar I. From June to August, the ingestion of a higher number of Peridinium, by instars III and IV, coincided with the decrease of Daphnia and the virtual disappearance of Bosmina in the environment (Fig. 3). In September-October, high consumption of cladocerans by late instars (Fig. 2) was coincident with peaks of Bosmina and relatively high densities of Daphnia (Fig. 3). From November to January, late intars consumed rotifers, "other algae" and "non-identified" in a higher proportion, when densities of both cladocerans were low.

There was a significant negative correlation between densities of $D$. gessneri and Chaoboridae larvae $(\mathrm{r}=-0.39, \mathrm{P}=0.003)$, regarding the whole sampling period of $1985 / 86$.

\section{Relation between predator mouth diameter and prey dimensions}

Maximum width, height, or diameter values of ingested organisms were closely related to the mouth diameter limit of the four instars (Fig. 4).

The frequency of occurrence of small prey (0.01-0.02 mm), represented by zooflagellates, as well as that of organisms a little larger (diameter or width 0.03-0.06), such as Peridinium and rotifers, were similar for instars I and II. The latter consumed also cladocerans (height $0.10-0.20 \mathrm{~mm}$ ), making the difference between their diets. Larger prey were ingested by late instars, until the width or height limits of $0.26 \mathrm{~mm}$, and $0.30 \mathrm{~mm}$, for instars III and IV, respectively.

Maximum prey dimensions (width, height, diameter) were close to the maximum mouth diameter of the larvae. The maximum prey length (e.g. 

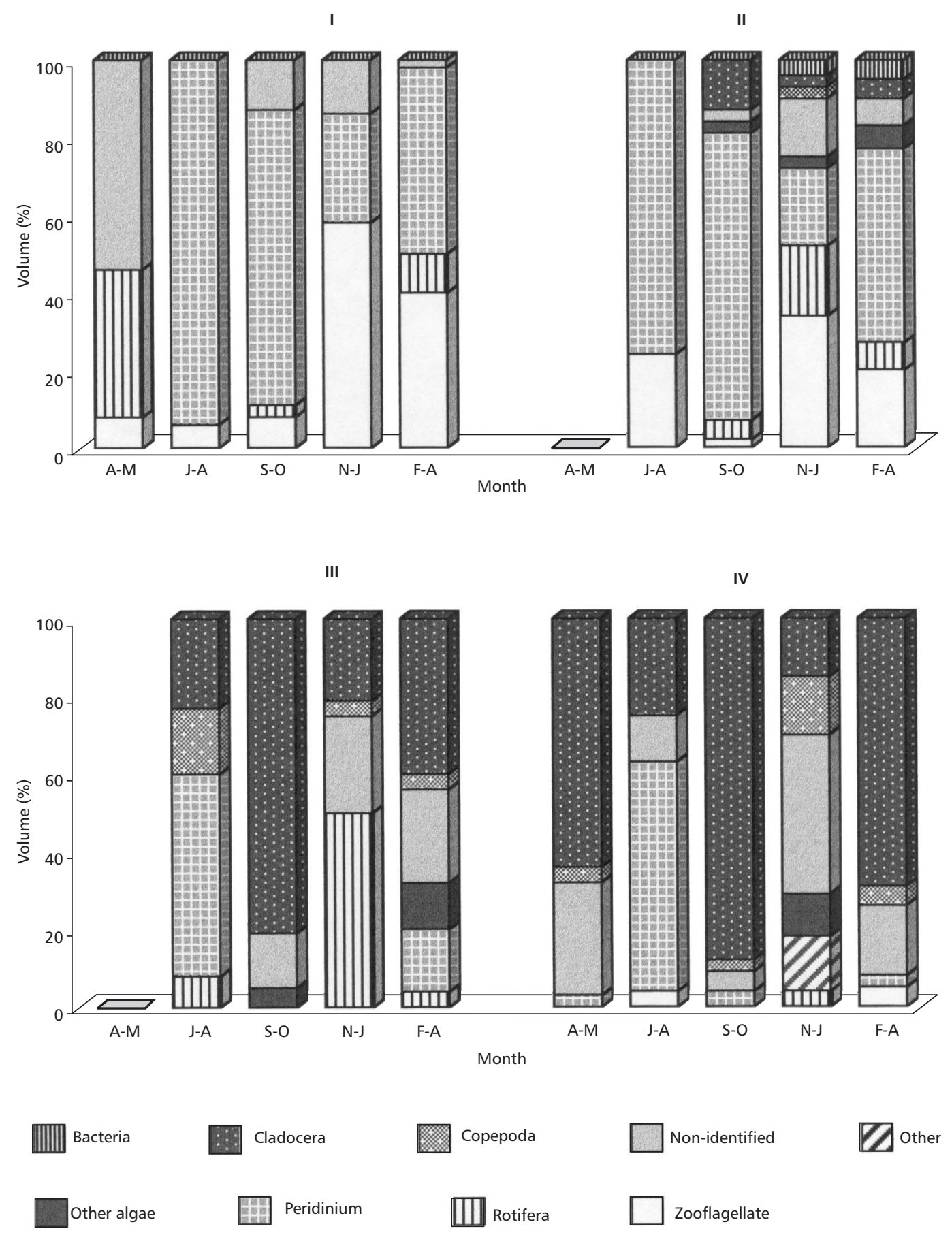

Fig. 2 - Temporal variation of items in the diet of the larvae I to IV, from April 1985 to April 1986. 


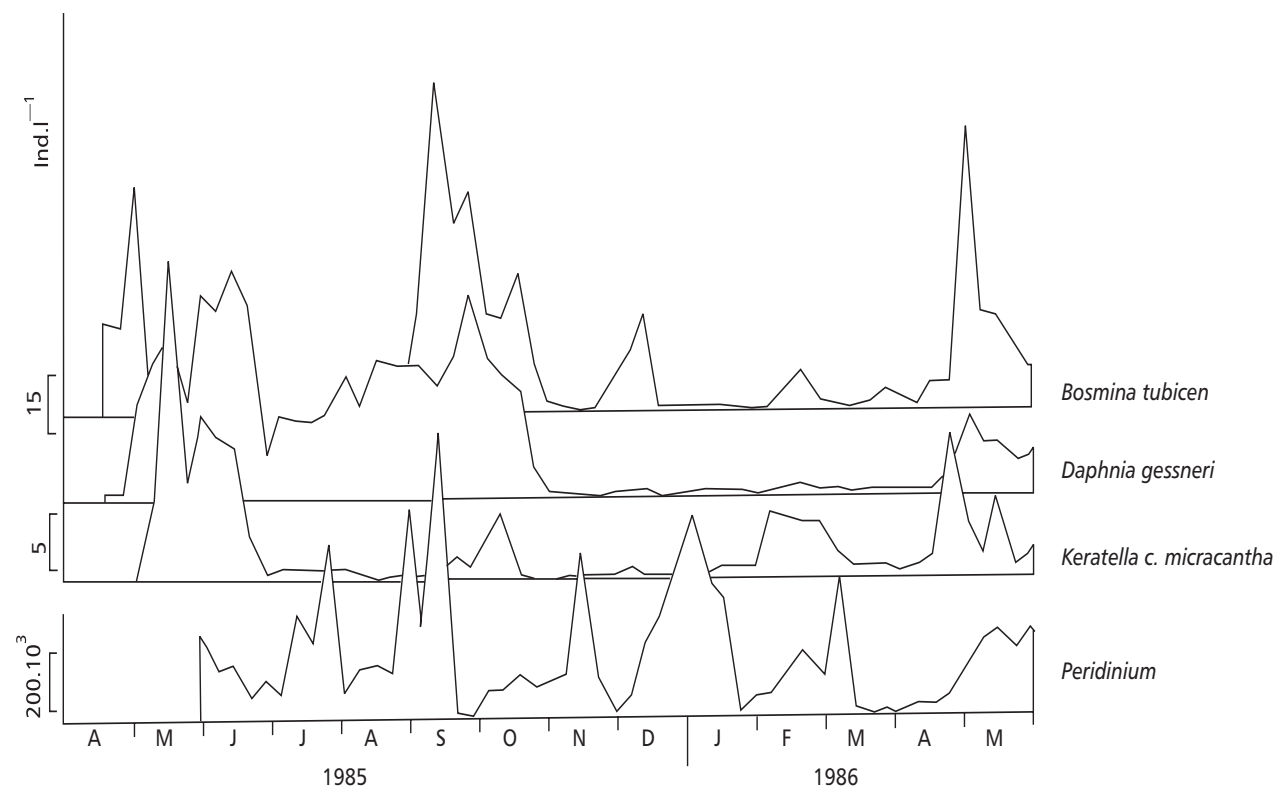

Fig. 3 - Density fluctuations of the main Chaoboridae prey, from April 1985 to May 1986.

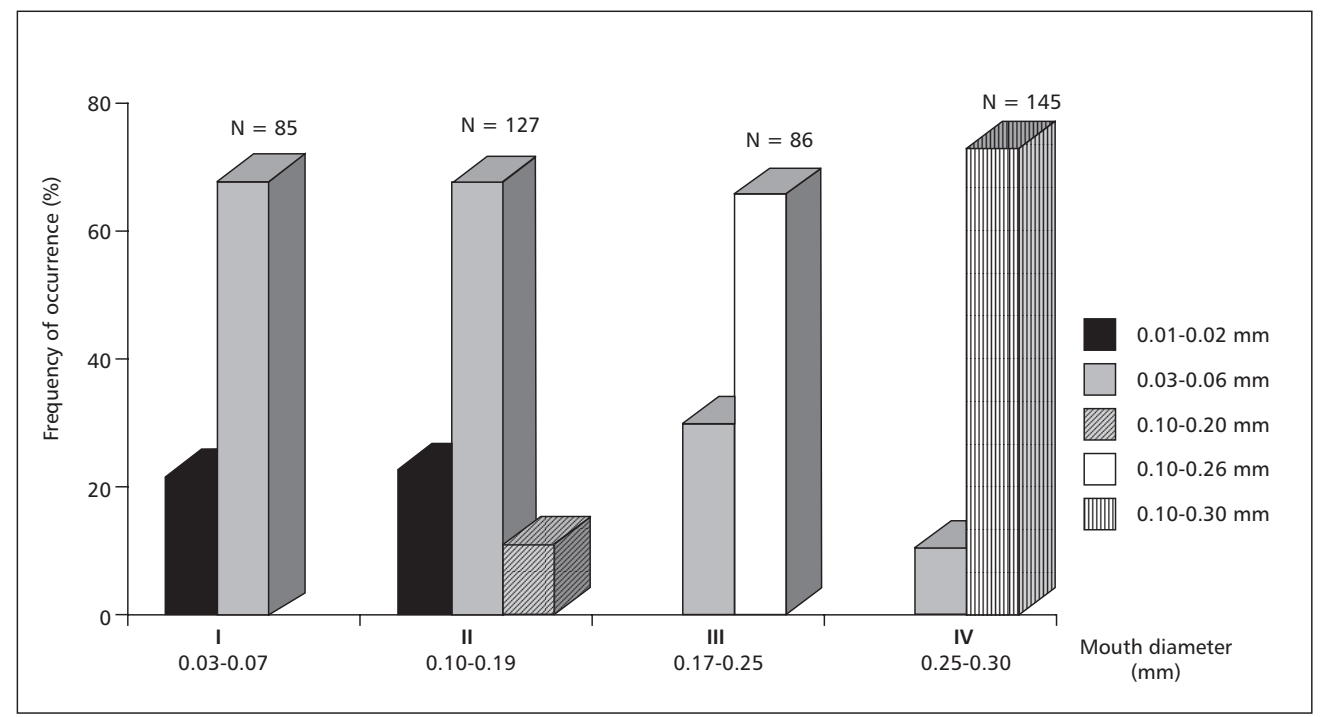

Fig. 4 - Frequency of occurrence of prey considering their dimensions (width, height, or diameter) and the range of mouth diameter in the four larval instars.

copepods, cladocerans), however, could exceed the predator mouth diameter.

\section{Selectivity of cladoceran prey}

The electivity index values clearly indicated the preference of instar IV for Bosmina, in three different occasions of low ( $<1$ ind. $\left.1^{-1} ; 10 / \mathrm{V} / 85\right)$, intermediate (11 ind.1 $\left.{ }^{-1} ; 20 / \mathrm{II} / 86\right)$, and high densities (51 ind. - $^{-1}$ 20/IX/85) (Fig. 5). Daphnia gessneri and Ceriodaphnia cornuta were avoided. In the same occasions, Bosmina was the only cladoceran prey ingested by the larvae III. 


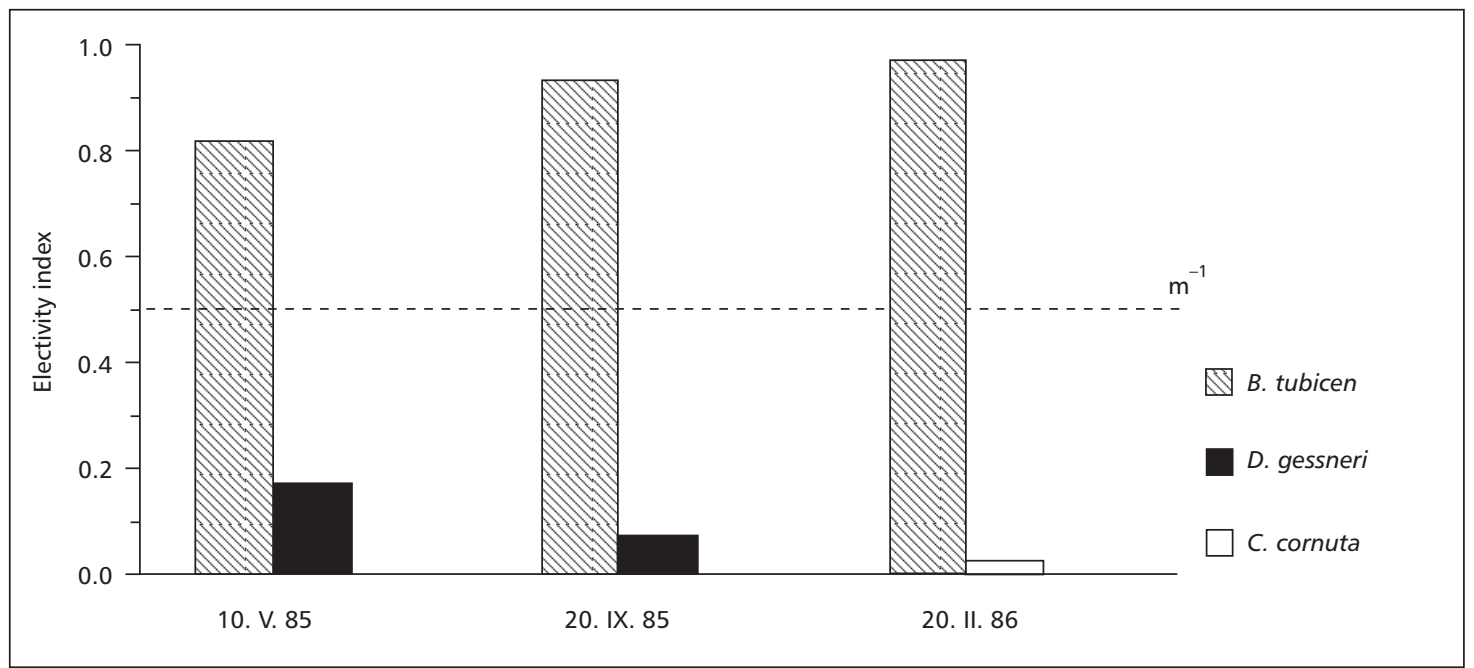

Fig. 5 - Electivity indices for the larvae IV on cladoceran prey, in three occasions. $m=$ number of prey.

\section{DISCUSSION}

The dinoflagellate alga Peridinium was an important component of the diet of Chaoboridae larvae in Lake Monte Alegre, mainly for early instars, the contribution of microcrustaceans, especially cladocerans, increasing to instars III and IV. Dinoflagellates, such as Peridinium and Ceratium, can be a significant item in the diets of other Chaoboridae (Hare \& Carter, 1987; Shei et al., 1988; Moore, 1988; Moore et al., 1994), and not an incidental one. The dinoflagellate Glenodinium was also part of a Chaoborus diet, although not always represented by a large biomass in the crops (Elser et al., 1987). It is possible that structures of the pharyngeal sphincter are responsible for crashing Peridinium shells (Hare \& Carter, 1987).

The ingestion of other algae by larvae in Lake Monte Alegre could be not incidental. Their higher contribution to the diet of instar III, however, occurred during the depression of the preferred prey Bosmina.

Preference for Bosmina, as found in this paper, was also observed in several lakes (Lewis, 1977; Elser et al., 1987; Yan et al., 1991). In one of the manipulated lakes, the latter authors related low densities of Bosmina longirostris with the increase of Chaoboridae predation. Neill (1981) found, in experiments, a supressing effect of Chaoborus on the population of Bosmina longirostris. The absence of Bosmina in a lake lacking fish was ascribed to Chaoboridae predation (von Ende \& Dempsey, 1981). In Lake Monte Alegre, Chaoboridae predation could be one of the factors controlling the population of Bosmina tubicen (Arcifa et al., 1992). Based on his own data and those from the literature, Lewis (1977) concluded that Bosmina was the first, and nauplius and Daphnia were the last in the rank order of selectivity of late Chaoboridae instars. The data of Lake Monte Alegre are in agreement with the rank positon of Bosmina and nauplius, but not that of Daphnia, which represented more than $15 \%$ of the cladocerans preyed by the instar IV.

Predation of larvae on young Daphnia gessneri in Lake Monte Alegre is consistent with their gape limited condition, and agree with observations of several authors, involving other Daphnia species (Lewis, 1977; Pastorok, 1980; Riessen et al., 1988; Shei et al., 1988).

According to Moore \& Gilbert (1987) rigid prey is swallowed long-wise, and consequently prey width is more important than length. Data presented here agree with their observations, once the prey width or height were comprised within the limits of the predator mouth diameter. Limitation of prey ingestion by the small Chaoboridae of Lake Monte Alegre is evidenced by the lack of copepod and cladoceran in the diet of instar I, ingestion of nauplius, copepodite, young Bosmina by the instar II, copepodite and adult copepod by instar III, and young Daphnia by instar IV. The advantage in 
exploiting larger organisms, but within the predator mouth limit, is shown by the higher frequency of larger items (see Fig. 4).

The suggestion that Chaoborus species are omnivores which prefer phytoflagellates even when animal prey is available (Moore et al., 1994) can be partially applied to larvae of Lake Monte Alegre. Instars I and II consumed more Peridinium than potential rotifer prey, for example, but instars III and IV fed on Peridinium when preferred animal prey were scarce or virtually absent.

Acknowledgments - I thank E. A. T. Gomes, A. J. Meschiatti, L.V. Lang, R. A. Rodrigues and R. M. Hamasaki for help in the field work. I am especially indebted to A. J. Meschiatti for helping in the diet evaluation.

\section{REFERENCES}

ARCIFA, M. S., 1997, Fluctuations and vertical migration of Chaoborus in a tropical Brazilian reservoir: Lake Monte Alegre. Acta Limnol. Brasil., 9: 93-103.

ARCIFA, M. S., MESCHIATTI, A. J. \& GOMES, E. A. T., 1990, Thermal regime and stability of a tropical shallow reservoir: Lake Monte Alegre, Brazil. Rev. Hydrobiol. trop., 23: 271- 281.

ARCIFA, M. S., GOMES, E. A. T. \& MESCHIATTI, A. J., 1992, Composition and fluctuations of the zooplankton of a tropical Brazilian reservoir. Arch. Hydrobiol., 123: 479-495.

ARCIFA, M. S. \& MESCHIATTI, A. J., 1993, Distribution and feeding ecology of fishes in a Brazilian reservoir: Lake Monte Alegre. Interciencia, 18: 302-313.

CHESSON, J., 1978, Measuring preference in selective predation. Ecology, 59: 211-215.

CRESSA, C. \& LEWIS Jr., W. M., 1984, Growth and development patterns in a tropical Chaoborus species and their ecological significance. Arch. Hydrobiol., 100: 21-28.

ELSER, M. M., von ENDE, C. N., SORRANO, P. \& CARPENTER, S. R., 1987, Chaoborus populations: response to food web manipulation and potential effects on zooplankton communities. Can. J. Zool., 65: 2846-2852.

HARE, L. \& CARTER, J. H. C., 1986, The benthos of a natural West African lake, with emphasis on the diel migrations and lunar and seasonal periodicities of the Chaoborus populations (Diptera, Chaoboridae). Freshwat. Biol., 16: 759-780.

HARE, L. \& CARTER, J. H. C., 1987, Zooplankton populations and the diets of three Chaoborus species (Diptera, Chaoboridae) in a tropical lake. Freshwat. Biol., 17: 275290.
LEWIS Jr., W. M., 1975, Distribution and feeding habits of a tropical Chaoborus population. Verh. Internat. Verein. Limnol., 19: 3106-3119.

LEWIS Jr., W. M., 1977, Feeding selectivity of a tropical Chaoborus population. Freshwat. Biol., 7: 311-325.

McGOWAN, L. M., 1974, Ecological studies on Chaoborus (Diptera, Chaoboridae) in Lake George, Uganda. Freshwat. Biol., 4: 483-505.

MOORE, M. V., 1988, Differential use of food resources by the instars of Chaoborus punctipennis. Freshwat. Biol., 19: 249-268.

MOORE, M. V. \& GILBERT, J. J., 1987, Age-specific Chaoborus predation on rotifer prey. Freshwat. Biol., 17: 223-236.

MOORE, M. V., YAN, N. D. \& PAWSON, T., 1994, Omnivory of the larval phantom midge (Chaoborus spp.) and its potential significance for freshwater planktonic food webs. Can. J. Zool., 72: 2055-2065.

NEILL, W. E., 1981, Impact of Chaoborus predation upon the structure and dynamics of a crustacean zooplankton community. Oecologia, 48: 164-177.

PASTOROK, R. A., 1980, Selection of Prey by Chaoborus Larvae: A Review and New Evidence for Behavioral Flexibility, pp. 538-554. In: W. C. Kerfoot (ed.), Evolution and Ecology of Zooplankton Communities, 793 p. The University Press of New England, Hanover.

REISS, F., 1977, Qualitative and quantitative investigations on the macrobenthic fauna of Central Amazon lakes. I. Lago Tupé, a black water lake on the lower Rio Negro. Amazoniana, 6: 203-235.

RIESSEN, H. P., SOMMERVILlE, J. W., CHIAPPARI, C. \& GUSTAFSON, D., 1988, Chaoborus predation, prey vulnerability, and their effect in zooplankton communities. Can. J. Fish. Aquat. Sci., 11: 1912-1920.

SHEI, P., IWAKUMA, T. \& FUJII, K., 1988, Feeding of Chaoborus flavicans larvae (Diptera: Chaoboridae) on Ceratium hirundinella and Daphnia rosea in a eutrophic pond. Jpn. J. Limnol., 49: 227-236.

SWIFT, M. C. \& FEDORENKO, A. Y., 1975, Some aspects of prey capture by Chaoborus larvae. Limnol. Oceanogr., 20: 418-425.

YAN, N. D., KELLER, W., MacISAAC, H. J. \& McEACHERN, L. J., 1991, Regulation of zooplankton community structure of an acidified lake by Chaoborus. Ecol. App., 1: 5265.

Von ENDE, C. N. \& DEMPSEY, D. O., 1981, Apparent exclusion of the cladoceran Bosmina longirostris by the invertebrate predator Chaoborus americanus. Am. Midl. Nat., 105: 240-248. 